\title{
Structural and hydrogeological features of a Lias carbonate aquifer in the Triffa Plain, NE Morocco
}

\author{
J. Sardinha ${ }^{\text {a }}$ J.F. Carneiro ${ }^{\mathrm{a}, *}$, Y. Zarhloule ${ }^{\mathrm{b}}$, A. Barkaoui ${ }^{\mathrm{b}}$, A. Correia ${ }^{\mathrm{c}}$, M. Boughriba ${ }^{\text {b }}$, A. Rimi ${ }^{\mathrm{d}}$, \\ B. El Houadi ${ }^{\mathrm{e}}$ \\ ${ }^{a}$ Geophysical Centre of Évora, Department of Geosciences, University of Évora, Évora, Portugal \\ ${ }^{\mathrm{b}}$ Laboratory of Hydrogeology-Environment, Faculty of Sciences, Oujda, Morocco

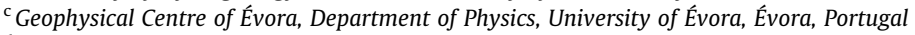 \\ ${ }^{\mathrm{d}}$ Institut Scientifique, Université Mohammed V-Agdal, Rabat, Morocco \\ ${ }^{\mathrm{e}}$ Hydraulic Basin Agency of Moulouya, Oujda, Morocco
}

\section{A R T I C L E I N F O}

\section{Article history:}

Received 11 January 2012

Received in revised form 19 June 2012

Accepted 22 June 2012

Available online 17 July 2012

\section{Keywords:}

Lias carbonate aquifer

Geological structure

Resource assessment

NE Morocco

\begin{abstract}
A B S T R A C T
The rising demand for water and the contamination of shallow water table aquifers has led authorities in NE Morocco to look for deeper groundwater resources in the Triffa Plain, namely in Lower Jurassic (Lias) dolomitic limestones. The liassic aquifer is of strategic importance for the development of the region, however, its hydrodynamic behaviour is poorly understood due to lack of hydrogeological data and block structure.

This article presents a first effort towards understanding the structure and hydraulic behaviour of the aquifer. Exploration borehole data and results from geophysical campaigns were integrated into a GIS environment to build a preliminary model of the aquifer structure. The aquifer behaves as an unconfined aquifer in the northern part of the Béni Snassen Mountains (the recharge area), but as it dips to the north, it becomes confined by marls and shales of the Middle/Upper Jurassic. Even though piezometric level data are scarce, a tentative piezometric map was produced. Three blocks separated by NW-SE trending faults in a horst and graben structure, with distinct flow behaviours were identified: Berkane, Fezouane and Sidi Rahmoun blocks. Those blocks also show differences in hydraulic conductivity distribution. As a result of the reaction with the dolomitic limestones, the groundwater is of calcium-magnesium bicarbonate type. Groundwater temperature as measured in springs ranges from $29^{\circ} \mathrm{C}$ to $37^{\circ} \mathrm{C}$ in springs and constitutes a potential low enthalpy geothermal resource.
\end{abstract}

(c) 2012 Elsevier Ltd. All rights reserved.

\section{Introduction}

The demographic and economic development of North African countries poses considerable challenges with regard to meeting water demands, with Morocco being no exception. Morocco is on the whole a dry country, with most of it under arid or semi-arid climate conditions, and the continuing development of the country is largely dependent on the ability to address the pressing needs for water supply. Groundwater resources play an important role in supplying water for irrigation, domestic and industrial uses across the whole country, including the Triffa Plain, in the north-east of Morocco.

The Triffa Plain, located within the municipality of Berkane, is primarily an agricultural area and thus places a considerable demand upon water for irrigation purposes. Until now, the Triffa

\footnotetext{
* Corresponding author.

E-mail address: jcarneiro@uevora.pt (J.F. Carneiro).
}

Plain has relied upon the exploitation of groundwater from a shallow unconfined aquifer. The water extraction volume obtained from this unconfined aquifer for irrigation in 2004 was estimated at $55.17 \mathrm{Mm}^{3} /$ year. However, the use of intensive agriculture practices, which rely on the use of pesticides and fertilisers, have led to the degradation of the groundwater quality in the unconfined aquifer (Zarhloule et al., 2009; Fekoul, 2011). High nitrate concentrations, multiple pesticide species and the overall salinisation of the groundwater have resulted in the need to explore additional groundwater sources.

Moreover, developments in tourism over recent years have led to increases in water demand which need to be met using both surface and groundwater sources, as neither source is able to provide a sustainable solution to the area's growing water needs. Hydrogeology studies in the area need to focus on less vulnerable, deeper aquifers, preferably confined or semi-confined, to avoid their potential pollution by agricultural practices. This article addresses one such aquifer in the Triffa Plain. The aquifer, composed of a confined sequence of carbonate rocks, has a vast potential for public 
water supply and for hydrothermal purposes. This article provides a preliminary overview of the ongoing structural and hydrogeological characterisation of this aquifer.

\section{Overview of the study area}

Eastern Morocco is topographically marked by the Middle Atlas to the west and the Oran Meseta to the east. It is characterised by a sequence of horsts and grabens of pre-Miocene age (Cataneo, 1985) of roughly NE-SW orientations (Michard, 1976). The region shows four distinct structural and sedimentary units (Hervoeut, 1985): the 'High- plateaux', the Guercif basin, the Taza-Oujda couloir, and the Triffa Plain.

The study area (the Triffa Plain) presents a surface area of about $750 \mathrm{~km}^{2}$ and is located in the north-eastern part of Morocco, $20 \mathrm{~km}$ south from the Mediterranean coast. It is limited by the Ouled Mansour hills to the north, the Béni Snassen Mountains to the south, the Kiss River to the east and the Moulouya River to the west (Fig. 1).

The climate conditions are semi-arid, with total rainfall not exceeding $327 \mathrm{~mm} /$ year and concentrated between January and April. The mean annual temperature is $17^{\circ} \mathrm{C}$, but seasonal variability is high, with an average minimum of $11^{\circ} \mathrm{C}$ and maximum of $25^{\circ} \mathrm{C}$. The average annual evapotranspiration is around $300 \mathrm{~mm} /$ year.

Geologic and geophysical studies of the region have been conducted by several researchers (e.g. Mongin and Moniton, 1952; Naciri, 1986; Ouahabi, 1987; Boudchich,1994; El Gout et al., 2010; Khattach et al., 2004; Chennouf et al., 2007) but an in-depth hydrogeological survey of the Triffa plain is missing. The Triffa Plain constitutes a wide synclinal depression formed by Mesozoic and Cenozoic geological formations, in which the sedimentary sequence overlays a Hercynian basement. Sedimentation proceeded continuously from the Triassic through to the Upper Jurassic period (Malm), but Cretaceous deposits are absent from the sequence due to generalised sea regression. Marine sedimentation continued during the Miocene transgression, but it gave way to a lacustrine and/or fluvial sedimentary sequence during the Upper Miocene and Pliocene (Fig. 2).

The Mesozoic formations crop out to the south within the Béni Snassen chain; they have a monoclinal structure, dipping $25^{\circ}$ to the north, and are crossed by two fault systems: $\mathrm{N} 140^{\circ}$ dextral and $\mathrm{N} 70^{\circ}$ sinistral, which have given rise to a system of small basins collapsing from south to north and from west to east. The Lower Jurassic (the Lias) is mainly composed by limestone and dolomite (Ouahabi, 1987; Naciri, 1986, 1994, Boudchich, 1994), with thicknesses varying from $30 \mathrm{~m}$ to over $200 \mathrm{~m}$ (Fig. 2).

\section{Hydrogeology}

The Triffa Plain is home to around 270,000 inhabitants and is an important agricultural area for Morocco, spanning an area of $36,060 \mathrm{Ha}$. The area's semi-arid climate conditions mean that irrigation of the land is essential, making the demand for water high for both agriculture and domestic purposes. Although groundwater from nearby shallow aquifers has a very high salinity, primarily due to the dissolution of evaporite rocks (Carneiro et al., 2010; Zarhloule et al., 2009), the shallow aquifers in the Triffa Plain have

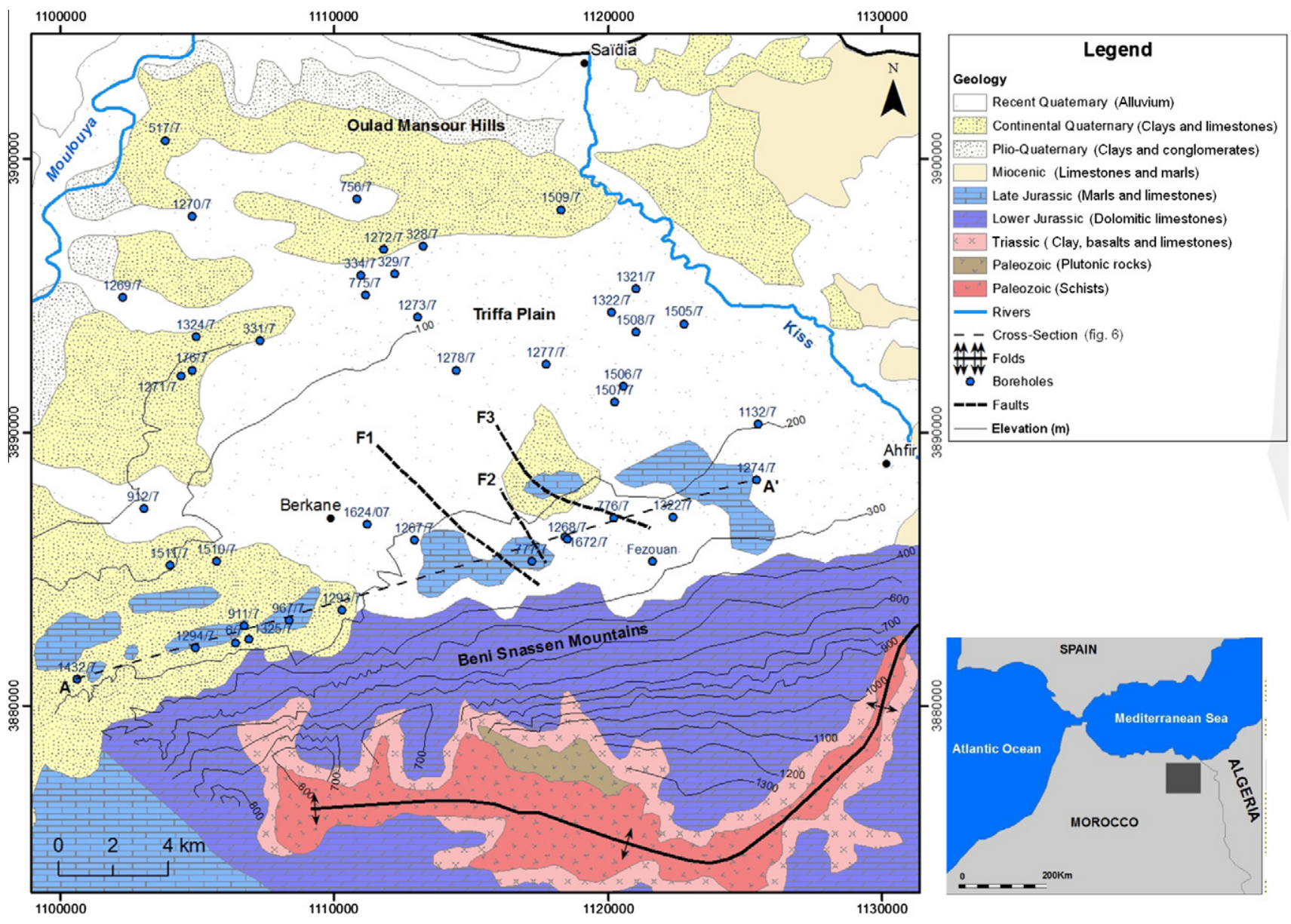

Fig. 1. Geologic sketch of the study area. 


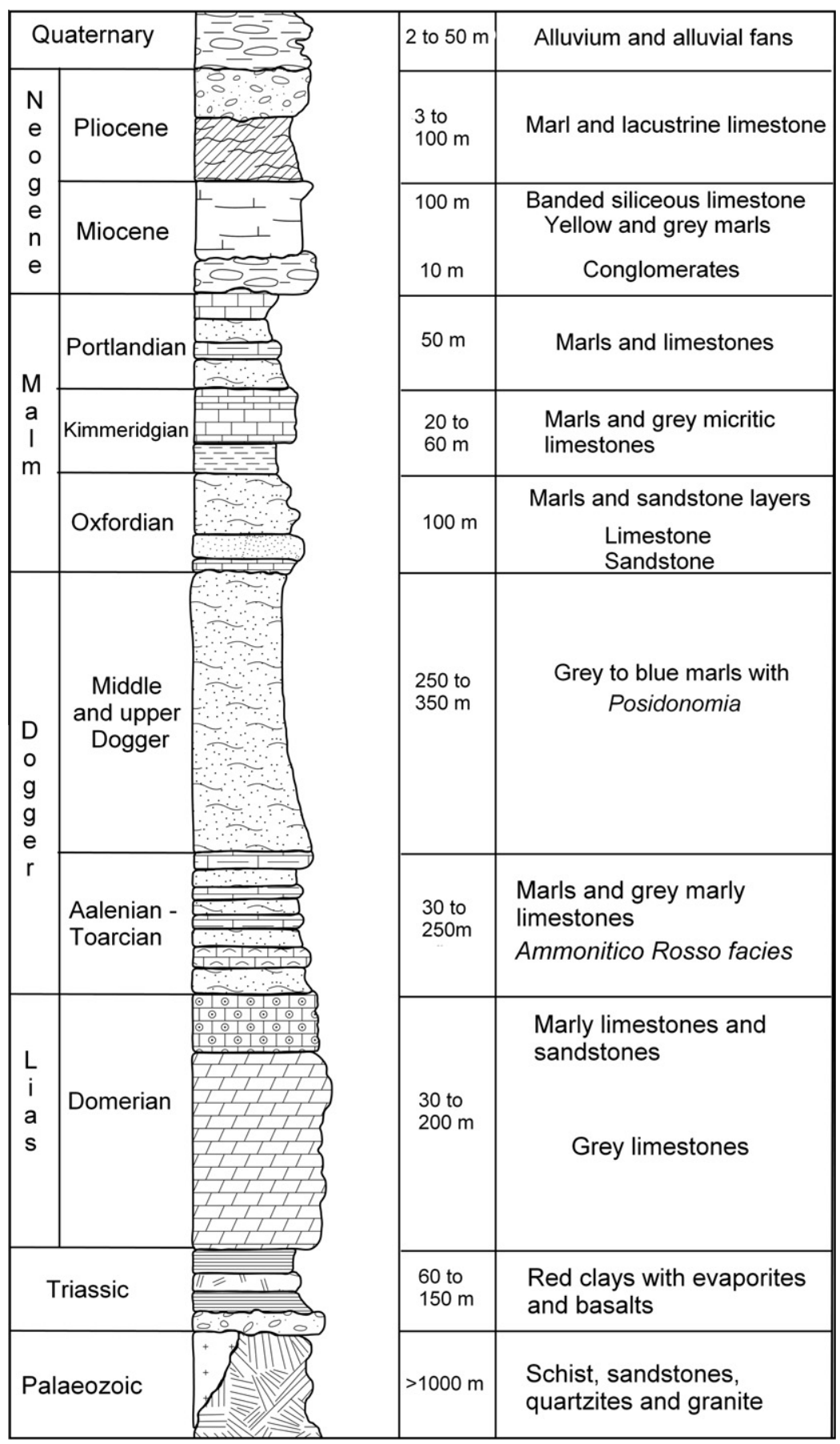

Fig. 2. Stratigraphic sequence in the Triffa Plain region.

provided a reliable source for irrigation for centuries. In recent years, however, the region has unfortunately witnessed a quantitative and qualitative deterioration of its groundwater resources.

Two aquifers are known in the study area:

(a) an unconfined aquifer in the Plio-Quaternary sediments of continental origin. This aquifer has been extensively exploited and is heavily contaminated by pesticides and nitrates. The aquifer has been the subject of several studies and its hydrogeologic behaviour and sources of contamination are well understood (El Mandour, 1998; El Idrysy and De Smedt, 2006; Boughriba et al., 2006; Zarhloule et al., 2009; Fekoul, 2011); (b) a confined aquifer in the Lower Jurassic (Lias) sediments, and which runs to depths on the order of $2000 \mathrm{~m}$. This aquifer, henceforth designated the 'Lias aquifer', has been used to a very limited extent for drinking water supply and is the subject of this paper.

\subsection{Structure of the Lias aquifer}

Highly permeable dolomitic limestones dating from the Lias crop out along the northern slope of the Béni Snassen mountains. The outcrop area covers about $220 \mathrm{~km}^{2}$ and the Lias formations dip towards the north, beneath the Triffa Plain, where they are overlain by low permeability marls and marly limestones of the 


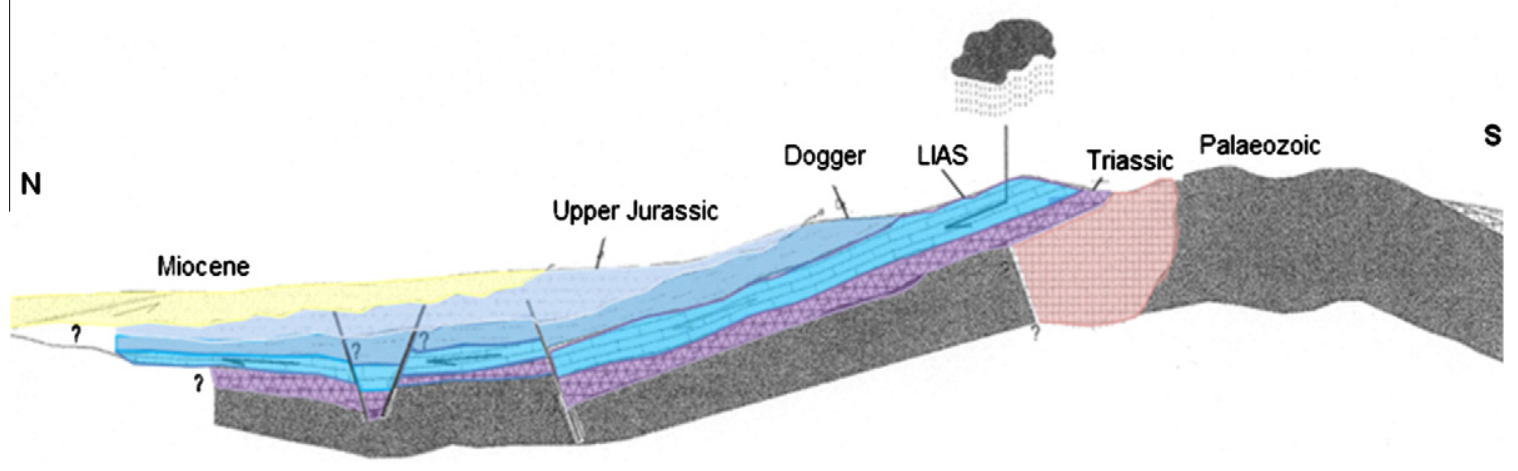

Fig. 3. Schematic geological cross-section of the study area along a N-S transverse (adapted from Geotlas, 2002).

Middle Jurassic, sometimes hundreds of metres thick. These low permeability units confine the Lias aquifer and isolate it from the contaminated shallow aquifer (Fig. 3).

It is the presence of thermal springs in the region, most notably those used for therapeutic purposes in the Fezouane village (Zarhloule et al., 2005, 2007), that has drawn attention to the hydrogeological potential of the Lias aquifer. Indeed, since the 1960's, deep wells have been drilled in attempts to characterise the aquifer and exploit the groundwater resources. Fig. 1 shows the location of 44 boreholes drilled in the Triffa Plain between 1964 and 2009. Only 27 of these boreholes intercept the Lias and all of them are located within the southern part of the Triffa Plain.

Fig. 4 illustrates the litho-stratigraphical logs of the two most relevant exploration boreholes present in the aquifer and outlines the thick confining units that overlay the aquifer. The confining units are mainly composed of Middle Jurassic marls and dolomites, which thicken towards the centre of the Triffa Plain to maximum values that exceed $900 \mathrm{~m}$.
Boreholes sited in the central and northern part of the plain (i.e., more distant from the outcrop area) failed to intercept the aquifer layers in the early Jurassic. It is not always clear from the older borehole logs if the depth reached was not enough to intercept the aquifer or if the Lias does not possess, in those areas, the dolomitic limestone characteristics that make it a good aquifer in the south of the basin. In either case, the logs provide evidence to indicate that the structural and stratigraphic setting of the aquifer possesses a certain complexity.

This complexity is also made evident from the 27 boreholes logs that did intercept the aquifer - either because the depth at which the aquifer occurred varied considerably between boreholes not very distant from each other, or because the hydraulic behaviour was different between the eastern and the western parts of the aquifer, with the former frequently showing artesian behaviour.

By the end of the 1990's, the pressing needs to access the groundwater resources led to efforts to clarify the geologic structure of the aquifer, resorting to the use of geophysical techniques.

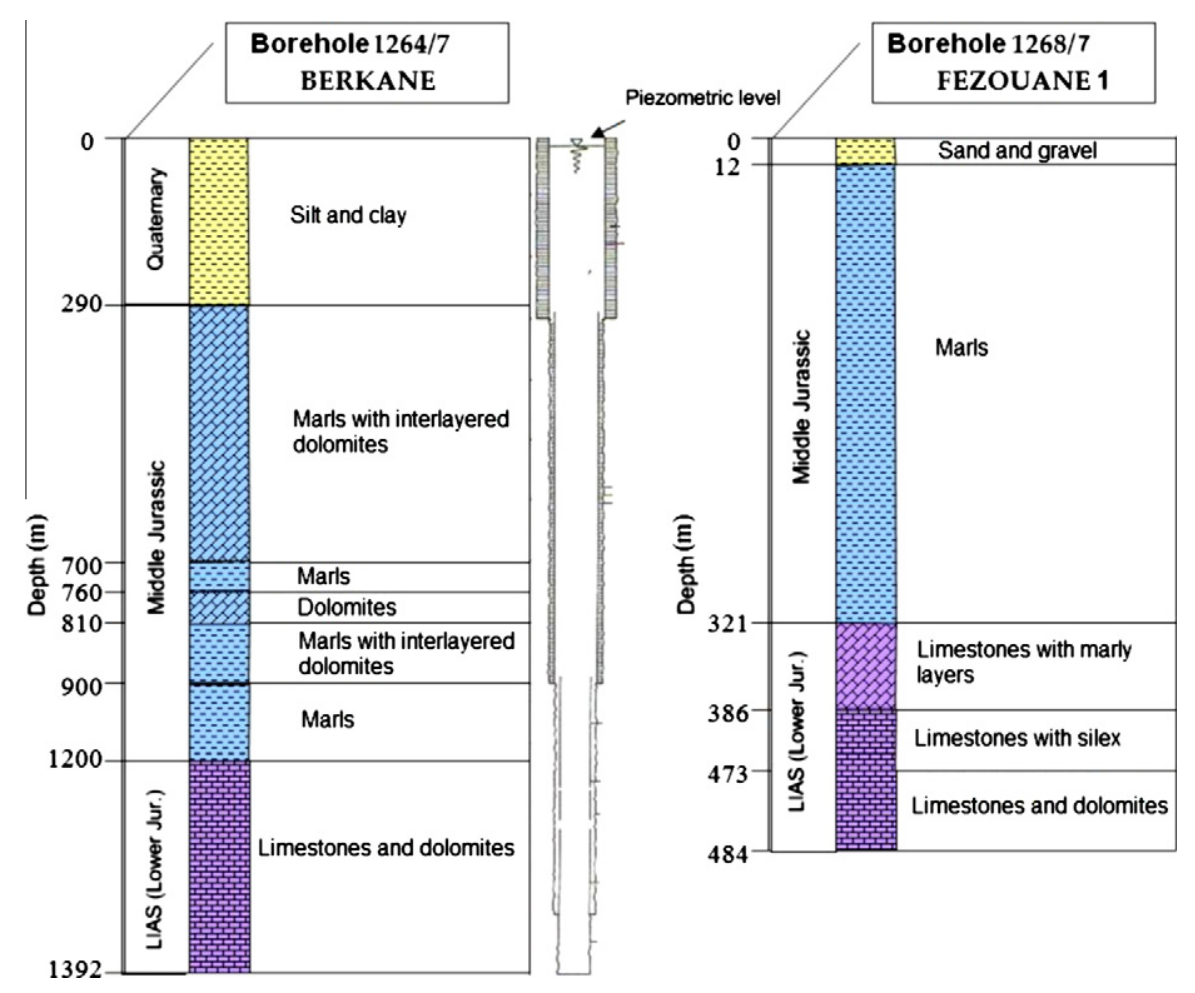

Fig. 4. Example litho-stratigraphic logs (see Fig. 1 for borehole locations). 


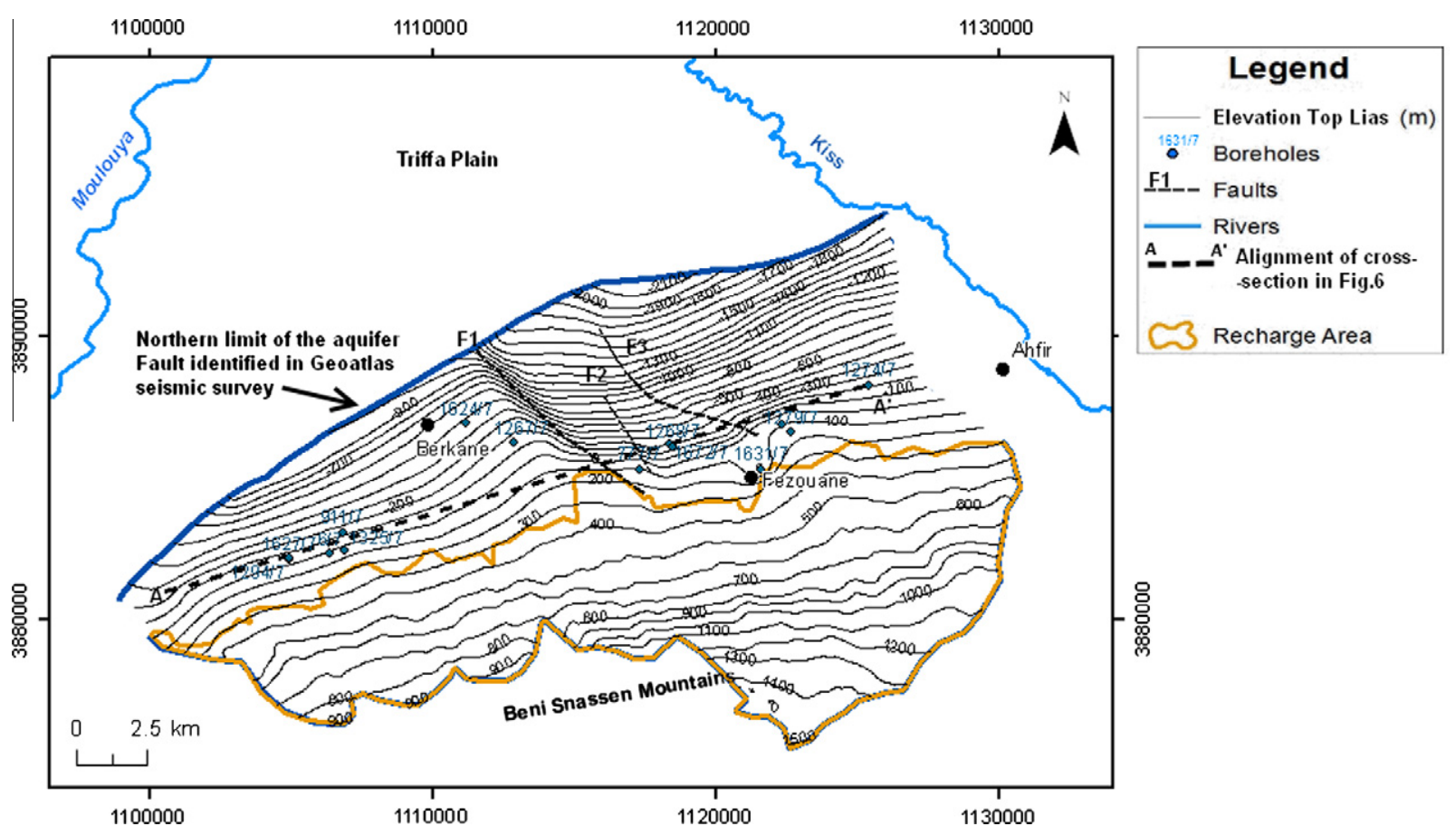

Fig. 5. Elevation (m) map of the top of the Lias aquifer. The Triffa plain has an average elevation of $200 \mathrm{~m}$.

Vertical electrical soundings were made (Geoatlas, 2000), followed in 2002 by seismic reflection profiling (Geoatlas, 2002). Both geophysical surveys identified the Lias aquifer but only in the southern part of the basin. Moreover, one important discontinuity striking approximately NE-SW was identified in the seismic profiles (Fig. 5). This NE-SW discontinuity is interpreted as a major fault that splits the Lias into two isolated sections: a southern section, where the Lias acts as a confined aquifer connected to the outcrops in the Béni Snassen mountains; and a northern section, in which the Lias may run deeper, isolated from any significant recharge, or where it may not act as an aquifer due to a facies transition to a lesser permeable lithology.

Three other important faults trending SSE/NNW, were identified in the field or by geophysical methods; they are assumed to extend to the Triffa plain. In Fig. 5 those faults are shown as F1, F2, and F3. They appear to play an important role in the compartment structure of the aquifer and may explain why the hydraulic behaviour amongst the blocks is different.

By coupling the borehole and the seismic survey data, it was possible to build a map of the top of the Lias aquifer in the southern part of the Triffa Plain (Fig. 6). This map will be of great relevance for future exploration efforts in the area. The map was built within an ArcGis environment by integrating: (i) the information on depth and thickness of the Lias intercepted by the boreholes (Table 1); (ii) the SRTM digital terrain model (DTM); and (iii) data from 2-D seismic surveys (Geoatlas, 2002). The Two-Way-Time maps for the top of the Lias resulting from the seismic reflection surveys were converted to depth maps by considering a uniform velocity of $3200 \mathrm{~m} /$ s (Geoatlas, 2002). Although a linear conversion to depths was performed, the resulting depth map of the top of the Lias is consistent with the Lias depths found in the boreholes. Along the recharge area in the Béni Snassen mountains, where the Lias crops out, the top of the aquifer was modelled as the ground surface represented by the DTM. The depth contours and the depths in the boreholes were then interpolated using the Inverse Distance Weighting algorithm for the whole area up to the NE-SW fault - thought to be the northern boundary of the aquifer.

Finally, the resulting depth map was subtracted from the DTM in order to convert it into an Elevation map of the top of the aquifer (Fig. 5). Elevation in the confined area can be as low as $-2100 \mathrm{~m}$, equivalent to depths of $2300 \mathrm{~m}$ beneath the plain. Although the location of faults F1, F2 and F3 were included in the GIS model, the interpolation did not consider any barrier effect imposed by these faults. Nonetheless, Fig. 6 clearly indicates sudden changes in the depth of the top of the aquifer near the location of these faults, in particular in the vicinity of fault F1.

The thickness of the aquifer is harder to define as only borehole $1432 / 7$ is fully penetrating, intercepting the total thickness of the aquifer across $38 \mathrm{~m}$. However, significant variations in its thickness exist towards the limits of the basin, as some of the boreholes intercept the Lias over a distance that exceeds $300 \mathrm{~m}$, yet do not reach the underlying Triassic formations (Fig. 6 and Table 1).

A

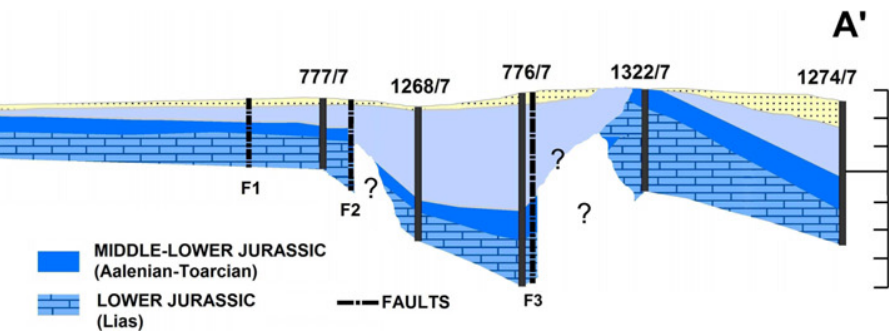

Fig. 6. Cross-section through the study area (see Fig. 5 for section location). 
Table 1

Borehole data.

\begin{tabular}{|c|c|c|c|c|c|c|}
\hline Borehole & Wellhead elevation (m) & Depth to aquifer (m) & Aquifer thickness & Piezometric level (m) & Specific capacity $\mathrm{Q} / \mathrm{s}_{\mathrm{w}}\left(\mathrm{m}^{2} /\right.$ day $)$ & Transmissivity, $T\left(\mathrm{~m}^{2} / \mathrm{s}\right)$ \\
\hline $6 / 7$ & 160 & 67 & 20 & 153.4 & 138.1 & $1.95 \mathrm{E}-03$ \\
\hline $777 / 7$ & 240 & 150 & 126 & 253.6 (artesian) & - & - \\
\hline $911 / 7$ & 143 & 115 & 95 & 134.8 & - & - \\
\hline $1267 / 7$ & 179 & 250 & 103 & - & - & - \\
\hline $1268 / 7$ & 215 & 321 & 163 & 220.2 (artesian) & 396.6 & $5.60 \mathrm{E}-03$ \\
\hline $1274 / 7$ & 241 & 405 & 117 & 242.0 (artesian) & - & $2.40 \mathrm{E}-02$ \\
\hline $1279 / 7$ & 251 & 232 & 163 & 248.0 & - & - \\
\hline $1294 / 7$ & 225 & 173 & 67 & 187.0 & - & $8.10 \mathrm{E}-02$ \\
\hline $1322 / 7$ & 242 & 65 & 305 & 212.8 & - & $5.40 \mathrm{E}-02$ \\
\hline $1325 / 7$ & 157 & 26 & 124 & 138.0 & 1770 & $2.50 \mathrm{E}-02$ \\
\hline $1624 / 7$ & 145 & 1030 & 359 & 126.8 & - & - \\
\hline $1627 / 7$ & 224 & 350 & 120 & 213.3 & - & - \\
\hline $1631 / 7$ & 255 & 325 & 155 & 257.6 (artesian) & - & $5.30 \mathrm{E}-03$ \\
\hline $1632 / 7$ & 560 & - & 155 & 507.0 & - & $6.30 \mathrm{E}-03$ \\
\hline $1672 / 7$ & 215 & 765 & 110 & 202.3 & 354.1 & $5.00 \mathrm{E}-03$ \\
\hline
\end{tabular}

\subsection{Hydraulic behaviour of the aquifer}

In order to understand the hydraulic behaviour of the aquifer, data was gathered on its hydrogeological features from existing wells and boreholes. Although the data does not allow to clarify all aspects of a conceptual model of the aquifer, its general hydraulic characteristics could be defined and provide insight for additional studies.

The aquifer is unconfined in the Béni Snassen mountains, but no data about the hydraulic information of the area is available since no boreholes have ever been drilled in the mountains. In the Triffa Plain the aquifer behaves as confined, often with artesian behaviour, as observed in boreholes $777 / 7,1268 / 7$ and $1631 / 7$. Table 1 presents data from fifteen of the 27 boreholes that intercept the aquifer.

Piezometric levels are scarce and refer to different years and different seasons. All fifteen boreholes in Table 1 are located in the plain, but only three (boreholes 777/7, 1268/7 and 1624/7) are operational and have provided recent piezometric level readings. The piezometric levels shown for all other boreholes refer to measurements recorded at the time each borehole was drilled, and thus refer to different years. Furthermore, the spatial distribution of the boreholes is not the most ideal for providing insight into the flow patterns since most boreholes are aligned along an ENE-WSW direction, this means that there is a lack of important information away from that alignment. Still, a tentative piezometric map was produced by interpolation of the data in Table 1 by kriging and is presented in Fig. 7.

The piezometric map allows us to define the main flow directions and establish differences imposed by the main faults mentioned above. However, the map needs to be read with caution, since it was built using measurements made in different years and seasons, and also because the number and distribution of measuring points is poor.

As expected, flow is generally from the Béni Snassen mountains (the recharge area) to the Triffa plain. The interpolation method intentionally did not consider any possible barrier effect that may be imposed by faults F1, F2 and F3. Nevertheless, in the plain, where the aquifer is confined, the NW-SE trending faults F1, F2 and F3 divide the aquifer into three blocks with distinct flow behaviours (Fig. 7).

In the eastern block, limited to the west by fault F3, and here designated as the Sidi Rahmoun block, flow is mainly towards the north. However, piezometric levels were only available from two boreholes in the block and the possibility cannot be discarded that flow may be primarily to the NE, into Algerian territory, where the aquifer continues.
The second block, denominated the Fezouane block, is limited by faults F1 and F3 and shows piezometric levels that are frequently above the ground level, which is consistent with the existence of artesian wells, often used for hydrothermal purposes. Here, the groundwater has the deepest circulation and highest temperatures of the three blocks.

The third block, the Berkane block, is situated to the west of fault F1 and piezometric levels are consistently lower than those from the Fezouane block. Here, the flow is radial, mainly towards the Berkane municipality, possibly due to more intense groundwater pumping in the vicinity of the town.

The piezometric level differences suggest that the three blocks are hydraulically isolated from each other. This subdivision of the aquifer into three distinct blocks is consistent with the 3-D structure (Figs. 5 and 6) as well as with the borehole logs and geophysical information, which show that the aquifer is deeper in the Fezouane block than in the Berkane block, possibly due to movement along the NW-SE trending faults. The nature of the aquifer and the presence of several compartments make it very difficult to set up an observation network.

The structural and groundwater flow distinctions between the three blocks is reflected in the hydraulic parameters of the aquifer. Again, data is scarce since the boreholes were drilled for exploration purposes and were not converted into groundwater wells. In the most recent boreholes, constant-rate aquifer tests have been conducted, while in older boreholes transmissivity values are provided in the original borehole logs. No indications are available about the type of aquifer tests performed, but it is most probably that they were short term constant-rate tests, as was usual practice in the region.

In total, nine transmissivity values are available, which vary between $1.95 \times 10^{-3}$ and $5.4 \times 10^{-2} \mathrm{~m}^{2} / \mathrm{s}$, with a mean value of $2.1 \times 10^{-2} \mathrm{~m}^{2} / \mathrm{s}$ (Table 1 ). Although transmissivity values are present in some borehole logs, others only provide indications of the specific capacity, $Q / s_{w}$, (Table 1 ). In such cases, the transmissivity was estimated according to Logan's approximation (Logan, 1964):

$T=1.22 Q / s_{w}$

where $T$ is transmissivity and $Q$ is the discharge rate and $s_{w}$ is drawdown in the pumping borehole.

Taking into account the thickness of the aquifer intersected by the boreholes, hydraulic conductivity is estimated to vary between $10^{-4} \mathrm{~m} / \mathrm{s}$ and $2 \times 10^{-4} \mathrm{~m} / \mathrm{s}$. Storativity values are not available, probably because the hydraulic tests were conducted in the absence of observation wells.

A map of hydraulic conductivity distribution in the aquifer shows some distinction between the three blocks, with the Fezou- 


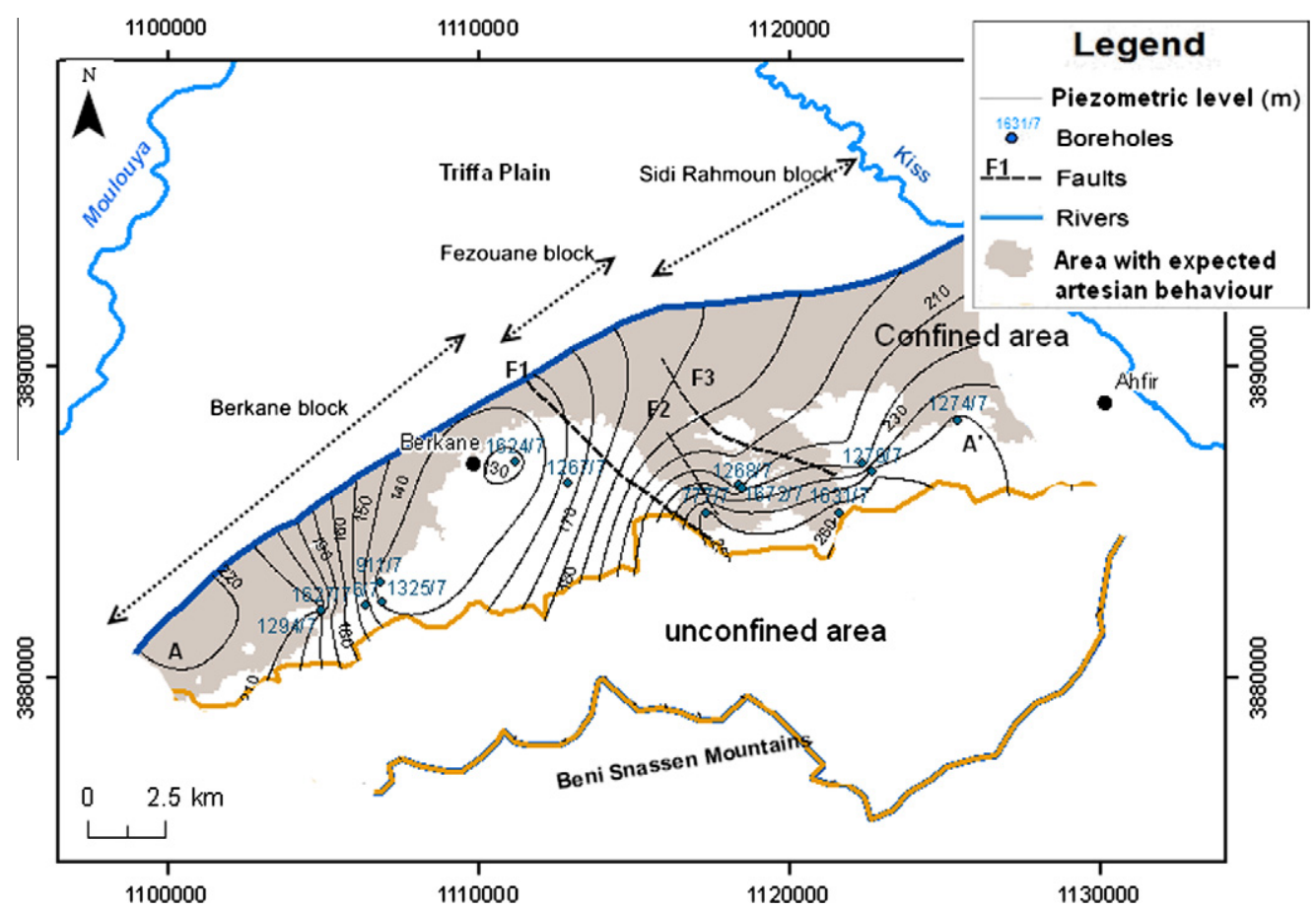

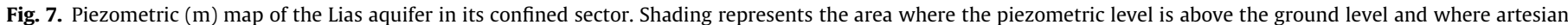
behaviour is expected. Notice that the Fezouane block shows a larger tendency for artesian behaviour than the other blocks.

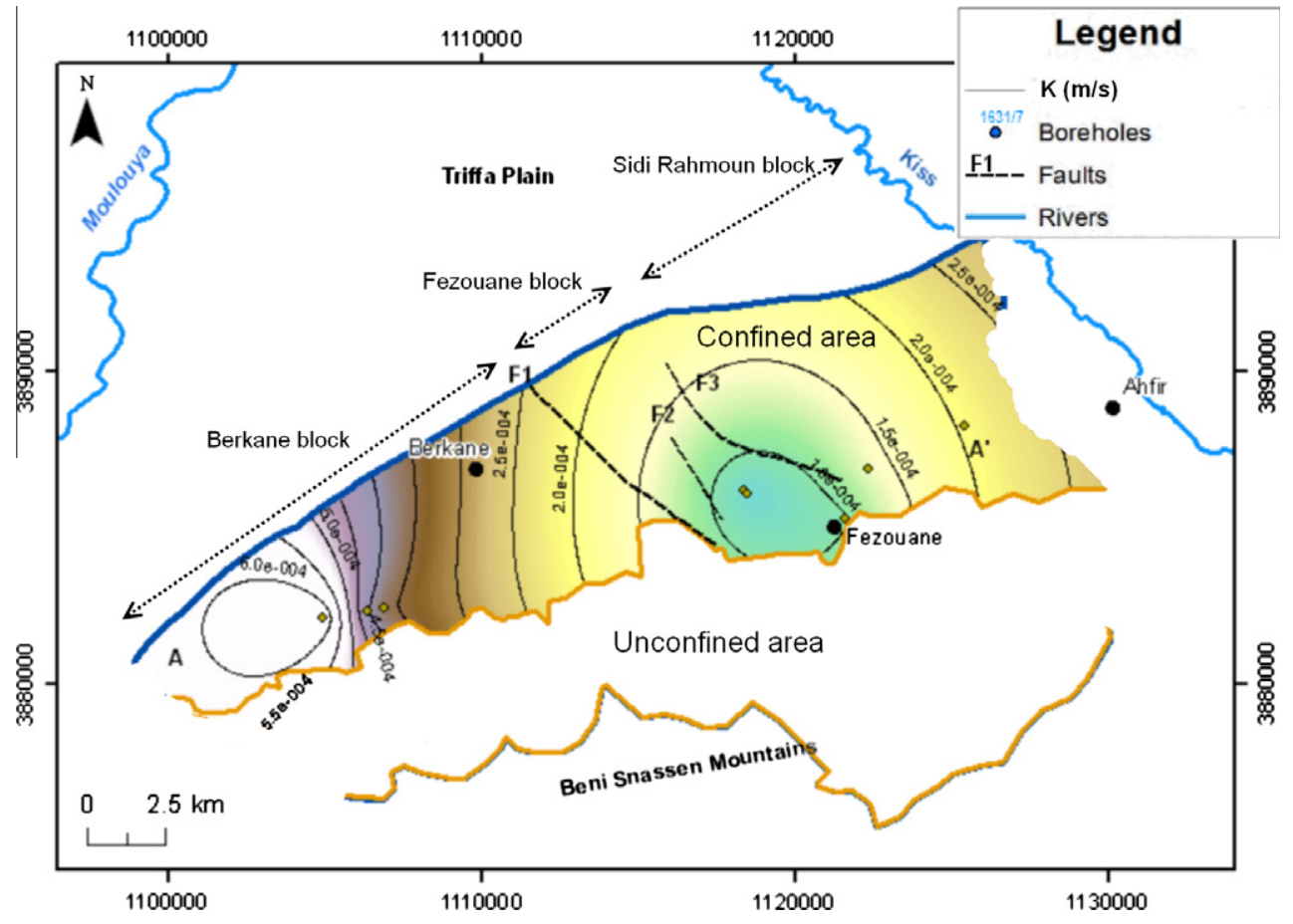

Fig. 8. Hydraulic conductivity (in $\mathrm{m} / \mathrm{s}$ ) distribution in the study area.

ane block showing systematic lower values of hydraulic conductivity than the Berkane block (Fig. 8). This is likely to be an effect of the greater aquifer depths in the Fezouane block, implying higher overburden pressures and possibly tighter fissures than in the shallower Berkane and Sidi Rahmoun blocks.

Despite the progress in identifying the main flow directions, it is not possible to clearly identify the discharge locations for the confined aquifer. The piezometric map does not contain enough data to make a reliable identification of discharge areas. The Moulouya River and the Kiss River may provide local discharge points where they cut the unconfined aquifer, but the confined aquifer is too deep to discharge to either of these rivers.

Estimations of the volume of aquifer recharge are difficult given the lack of data about surface run-off and the lack of reliable precipitation measurements in the Béni Snassen mountains. Measurements from several weather stations in the Triffa Plain indicate 
annual precipitation to amount to an average of $327 \mathrm{~mm} /$ year. Studies in similar geologic and geographic environments south of the Béni Snassen, namely the Oujda mountains located about thirty $\mathrm{km}$ to the south, assumed an infiltration rate of $14 \%$. Given that the outcrop area of the Béni Snassen is $220 \mathrm{~km}^{2}$, assuming a similar infiltration rate would give a volume of recharge of $10.1 \mathrm{hm}^{3} /$ year. This estimate must be taken with caution, particularly due to the semi-arid conditions of the area and the strong seasonal character of precipitation and evapotranspiration. Given the range of uncertainty, an infiltration rate between $10 \%$ and $15 \%$ might be assumed, which amounts to an annual recharge of $7.2-10.8 \mathrm{hm}^{3} /$ year.

Discharge values from the Lias aquifer could only be collected for the Fezouane region, which is exploited for therapeutic purposes. The flow rate is minimal $(2.4 \mathrm{l} / \mathrm{s})$, but there may be associated springs along the rivers in the Béni Snassen mountains where the aquifer is unconfined. Furthermore, the piezometric map indicates that flow in the Berkane block is radial, converging in the Berkane municipality and indicating relevant groundwater exploitation in the area.

\subsection{Hydrochemical facies and groundwater temperature}

Groundwater samples from four artesian wells (777/7, 1268/7, $1274 / 7$ and 1279/7) were collected and chemical analyses for the main chemical components were done, with the aim of clarifying the geochemical facies of the groundwater in the Lias aquifer (Table 2). The geochemical features of the four samples are related with the dolomitic limestone through which the groundwater flows, as a result of the reaction of the groundwater with the rock. $\mathrm{HCO}_{3}^{-}, \mathrm{Mg}^{2+}$ and $\mathrm{Ca}^{2+}$ were the dominant ions (Fig. 9). The total dissolved solids (TDS) varied between $130 \mathrm{mg} / \mathrm{l}$ and $500 \mathrm{mg} / \mathrm{l}$, but $\mathrm{pH}$ was fairly constant, ranging between 7.3 and 7.9. The groundwater facies is calcium-magnesium-bicarbonate, $\mathrm{Ca} \quad(\mathrm{Mg})-\mathrm{HCO}_{3}$. Occasional turbidity was interpreted as being due to flow in karstic conditions.

Also interesting is the relatively high temperature of the groundwater in the Lias aquifer; water temperatures measured in springs vary from 28 to $37^{\circ} \mathrm{C}$, these values are above what would be expected for wells that are not so distant from the recharge area. Studies done by the authors and presented in Rimi et al. (2012) indicate that geothermal gradients are rather high in some boreholes; in particular, borehole $1624 / 7$ (Berkane) has an average geothermal gradient higher than $110^{\circ} \mathrm{C} / \mathrm{km}$ at depths greater than $300 \mathrm{~m}$, and borehole 1672/7 (Fezouane 2), has a geothermal gradient was found to be $49^{\circ} \mathrm{C} / \mathrm{km}$. Unsurprisingly the area is known for its hydrothermal potential, especially in the Fezouane block. Details regarding the potential hydrothermal and geothermal applications of groundwater from the Lias aquifer are discussed in Rimi et al. (2012).

\section{Conclusions and recommendations}

The Lias aquifer in the Berkane region, NE Morocco, holds great potential as a prospective water and hydrothermal resource. Although several studies have been conducted in the past by the regional water authority, no systematic approach to understand

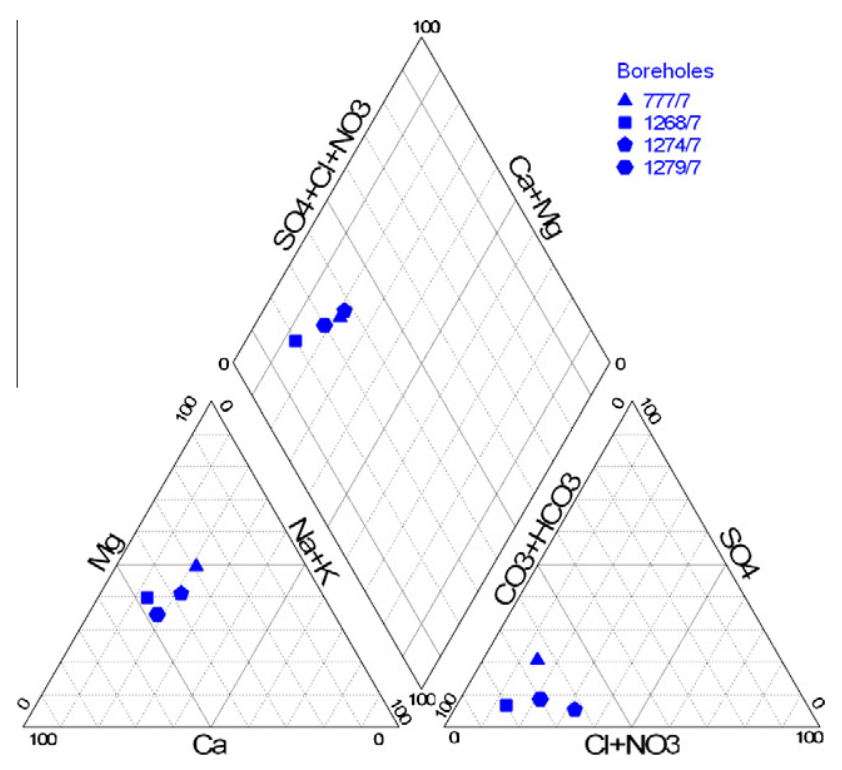

Fig. 9. Piper diagram of sampled groundwaters.

the structural and the hydraulic properties of the aquifer had ever been undertaken prior to the present study.

Using the information from the borehole logs and data from several geophysical campaigns, it was possible to build a preliminary model of the aquifer's structure. The model consists of three blocks (the Berkane block, the Fezouane block and the Sidi Rahmoun block), which result from a set of NW-SE trending faults that divide the aquifer in a horst and graben structure. The three blocks show different flow directions and are unlikely to be hydraulically connected; the piezometric level in the Fezouane block is systematically higher than in the other two blocks and, very often, shows artesianism.

However, some issues relating to the structure and geometry of the aquifer remain to be clarified. It is known that an NE-SW trending fault limits the aquifer to the north, but its limit to the east is not clear and apart from some minor springs in the outcropping area of the aquifer, it is not clear where discharge occurs. Indeed, the aquifer's discharge may reside in Algerian territory. Hopefully, some progress about the unknown discharge area can be made if some of the 24 closed wells are re-opened and measured for groundwater level; this will allow constructing a more accurate piezometric map.

Renewable resources in the aquifer are estimated to be around $7-10 \mathrm{hm}^{3} /$ year, considering an infiltration rate of $10-15 \%$, but this estimate could be improved through the use of time series of piezometric levels and run-off measurements in the Béni-Snassen mountains.

According to the Moroccan requirements the water from the Lias aquifer is potable, being of a Calcium-Magnesium bicarbonate facies; its chemical characteristics are a result of its reaction with the dolomitic limestones of the aquifer. Temperature is high and hydrothermal facilities already exist or are being built in the region to improve the economy of an otherwise rural area.

Table 2

Chemical analysis of groundwater samples.

\begin{tabular}{|c|c|c|c|c|c|c|c|c|c|c|c|}
\hline Borehole & $T\left({ }^{\circ} \mathrm{C}\right)$ & $\mathrm{pH}$ & TDS (mg/l) & $\mathrm{K}^{+}(\mathrm{mg} / \mathrm{l})$ & $\mathrm{Na}^{+}(\mathrm{mg} / \mathrm{l})$ & $\mathrm{Ca}^{2+}(\mathrm{mg} / \mathrm{l})$ & $\mathrm{Mg}^{2+}(\mathrm{mg} / \mathrm{l})$ & $\mathrm{Cl}^{-}(\mathrm{mg} / \mathrm{l})$ & $\mathrm{HCO}_{3}^{-}(\mathrm{mg} / \mathrm{l})$ & $\mathrm{SO}_{4}^{2-}(\mathrm{mg} / \mathrm{l})$ & $\mathrm{SiO}_{2}(\mathrm{mg} / \mathrm{l})$ \\
\hline $777 / 7$ & 28 & 7.3 & 360 & 1.5 & 30 & 37 & 38 & 35 & 268 & 67.5 & 12.3 \\
\hline $1268 / 7$ & 37 & 7.9 & 340 & 1.1 & 22 & 70 & 36 & 28 & 292 & 19.5 & 15.2 \\
\hline $1274 / 7$ & 29 & 7.4 & 500 & 1.7 & 43 & 66 & 44 & 106 & 353 & 24.3 & 13.2 \\
\hline $1279 / 7$ & 29 & 7.8 & 130 & 1.7 & 32 & 74 & 33 & 60 & 341 & 33.4 & 12.8 \\
\hline
\end{tabular}


Water scarcity in the region coupled with the increasing contamination of shallow aquifers due to agricultural practices requires that more systematic studies of the Lias aquifer are performed. The major difficulty faced in the construction of the preliminary model presented here regards the characterisation and the identification of the aquifer's limits and its discharge area, and thus provide the main focus for future research.

\section{Acknowledgements}

This study was performed in the scope of the bilateral Project CNRST-GRICES SDT/09, funded by FCT (the Portuguese Foundation for Science and Technology) and CNRST (the Moroccan National Centre for Scientific and Technology Research).

\section{References}

Boudchich, L., 1994. Lias-Dogger des Beni Snassen Orientaux (Maroc nord-oriental). Successions stratigraphiques, évolution tectono-sédimentaire et micropaléontologique. Thèse d'état, Univ. Oujda, p. 253.

Boughriba, M., Melloul, A., Zarhloule, Y., Ouardi, A., 2006. Extension spatiale de la salinisation des ressources en eau et modèle conceptuel des sources salées dans la plaine des Triffa (Maroc nord-oriental). Comptes Rendus Geosciences 338 (11), 768-774.

Carneiro, J.F., Boughriba, M., Correia, A., Zarhloule, Y., Rimi, A., El Houadi, B., 2010. Evaluation of climate change effects in a coastal aquifer in Morocco using a density-dependent numerical model. Environ. Earth Sci. 61 (2), 241-252.

Cataneo, 1985. Les formations du Jurassique supérieur et du Crétacé inférieur de l'avant-pays rifain oriental (Maroc). Thèse SC. Dijon. France, p. 327.

Chennouf, T., Khattach, D., Milhi, A., Andrieux, P., Keating, P., 2007. Principales lignes structurales du Maroc nord-oriental: apport de la gravimétrie. Comptes Rendus Geosciences 339 (6), 383-395.

El Gout, R., Khattach, D., Houari, M.R., Kaufmann, O., Aqil, H., 2010. Main structural lineaments of north-eastern Morocco derived from gravity and aeromagnetic data. J. African Earth Sci. 58 (2), 255-271.

El Idrysy, E.H., De Smedt, F., 2006. Modelling groundwater flow of the Triffa aquifer, Morocco. Hydrogeol. J. 14, 1265-1276.

EL Mandour, A., 1998. Contribution à l'étude hydrogéologique de la plaine de Triffa: salinisation et modélisation. Thèse de Doctorat. PHD. Faculté des sciences d'Oujda, Maroc, p. 206.

Fekoul, 2011. Etude de la nappe phréatique de la plaine des Triffa (Mroc nordoriental): contamination par les nitrates, la salinité et les pesticdes. Thèse en cours, université Mohamed I, Oujda.
Geoatlas, 2000. Etude de synthèse des données géophysique existantes plaine des Triffas, Direction Générale de l'Hydraulique. Direction de la Recherche et de la Planification de l'Eau. Rabat, Maroc, p. 36.

Geoatlas, 2002. Etude géophysique par sismique réflexion dans la plaine des TriffasRégion d'Oujda. Direction Générale de l'Hydraulique. Direction de la Recherche et de la Planification de l'Eau. Rabat, Maroc, p. 35.

Hervoeut, H., 1985. Géodynamique alpine (Trias-actuel) de la marge septentrionale de l'Afrique du Nord du bassin de Guercif (Maroc oriental), Thèse d'Etat, Univ. Pau, France, p. 367.

Khattach, D., Keating, P., Mili, E., Chennouf, T., Andrieux, P., Milhi, A., 2004. Apport de la gravimétrie à l'étude de la structure du bassin des Triffa (Maroc nordoriental): implications hydrogéologiques. Comptes Rendus Geosciences 336 (16), 1427-1432.

Michard, 1976. Eléments de géologie marocaine. Note et mémoire du service géologique du Maroc, vol. 252, p. 422.

Logan, J., 1964. Estimating transmissibility from routine production tests of water wells. Ground Water 2, 35-37.

Mongin, Moniton, 1952. Nouvelles observations stratigraphiques et paléontologiques sur le Juarssique supérieur de la basse Moulouya. Notes et Mem. Serv. Geol. Maroc. T6, vol. 95, pp. 135-159.

Naciri, T., 1986. Etude lithostratigraphique et structurale des Beni-Snassen (Maroc). Thèse Doct. 3ème cycle Univ. Pau et pays de l'Adour, inédite, p. 236.

Naciri, T., 1994. Evolution sédimentaires, environnements et contrôles, dans le lias dogger des Béni-snassen orientaux (Maroc, Nord oriental) Doc. Es. Sciences. Univ. Med. Ier. Oujda, p. 243.

Ouahabi, B.A., 1987. Le Lias moyen et supérieur des Béni Snassen Orientaux et des Zekkara (Maroc Oriental). Biostratigraphie-Paléontologie des Hildoceras. Thèse 3ème cycle, Univ. Claude Bernard Lyon1.

Rimi, A., Zarhloule, Y., Barkaoui, A.E., Correia, A., Carneiro, J., Verdoya, M., Lucazeau, F., 2012. Towards a de-carbonized energy system in north-eastern Morocco: prospective geothermal resource. Renew. Sust. Energy Rev. 16, 2207-2216.

Zarhloule, Y., Bouri, S., Lahrach, A., Boughriba, M., El Mandour, A., Ben Dhia, H., 2005 Hydrostratigraphical Study, Geochemistry of Thermal Springs, Shallow and Deep Geothermal Exploration in Morocco: Hydrogeothermal Potentialities. World Geothermal Congress Avril 2005, Turky, p. 1-13.

Zarhloule, Y., Boughriba, M., Rimi, A., Lahrach, A., 2007. Les provinces hydrogéothermiques du Maroc Potentialités et possibilités d'utilisations. Bilan sur les sources d'énergie renouvelables au Maroc. Chapitre du livre UNESCO. Les énergies renouvelables au Maroc - Le débat est lancé. ISBN9954-8068-2-2 UNESCO, p. 164.

Zarhloule, Y., Fekkoul, A., Boughriba, M., Kabbabi, A., Carneiro, J., Correia, A., Rimi, A. Houadi, B., 2009. Climate change and human activities impact on the groundwater of the Eastern Morocco: case of Triffa plain and shallow coasta Mediterranean aquifer at Saïdia. Innovation in Groundwater Governance in MENA region Journal no. 14 of SIWI, Stockholm, p. 13-17. 